\title{
Analisis Kandungan Klorofil Daun Mangga (Mangifera indica L.) pada Tingkat Perkembangan Daun yang Berbeda
}

\author{
Lusia Sumenda ${ }^{1)}$, Henny L. Rampe ${ }^{2)^{*}}$, Feky R. Mantiri') \\ ${ }^{1)}$ Alumni Jurusan Biologi Fakultas MIPA Universitas Sam Ratulangi Manado \\ 2) Jurusan Biologi Fakultas MIPA Universitas Sam Ratulangi Manado \\ E-mail korespondensi :hennyrampe@yahoo.co.id
}

Diterima 2 Maret 2011, diterima untuk dipublikasikan 16 Juli 2011

\begin{abstract}
Abstrak
Kajian tentang kandungan klorofil pada daun mangga dengan perbedaan warna pada tingkat perkembangan yang berbeda belum banyak dilakukan. Penelitian ini bertujuan untuk membandingkan kandungan klorofil daun mangga (Mangifera indica L.) pada tingkat perkembangan daun yang berbeda. Setelah daun diekstrak dengan alkohol 95\%, kandungan klorofil diukur dengan menggunakan spektrometer tipe Novaspec III pada $\lambda 649$ dan $665 \mathrm{~nm}$. Hasil penelitian menunjukkan perbedaan kandungan klorofil daun pada tingkat perkembangan yang berbeda.

Kata kunci: daun mangga, klorofil, perkembangan
\end{abstract}

\section{Abstract}

The study on chlorophyll concentration of mango leaf with different colour and different stage of development has not been conducted thoroughly. This study aimed to compare the chlorophyll concentration of mango leaf with different stage of development. After extracting leaf chlorophyll using alcohol 95\%, chlorophyll concentration was measured using spectrometer (Novaspec III) on $\lambda 649$ and 665 $\mathrm{nm}$. The result showed that the chlorophyll concentration was different among the leaves with different stages of development.

Keywords: chlorophyll, development, mango leaf

\section{PENDAHULUAN}

Pertumbuhan

perkembangan

dan

tumbuhan

dipengaruhi oleh faktor eksternal dan internal. Faktor-faktor eksternal utama adalah tanah, kelembaban, cahaya dan air. Faktor-faktor internal dapat mencakup gen, hormon, struktur anatomi dan morfologi organ tumbuhan serta kandungan klorofil (Sasmitamihardja dan Siregar 1997). Klorofil adalah pigmen berwarna hijau yang terdapat dalam kloroplas. Pada tumbuhan tingkat tinggi, kloroplas terutama terdapat pada jaringan parenkim palisade dan parenkim spons daun. Dalam kloroplas, pigmen utama klorofil serta karotenoid dan xantofil terdapat pada membran tilakoid (Salisbury dan Ross 1991).
Klorofil berasal dari proplastida yaitu plastida yang belum dewasa, kecil dan hampir tidak berwarna dan sedikit atau tanpa membran dalam. Proplastida membelah saat embrio berkembang, dan menjadi kloroplas ketika daun dan batang terbentuk. Pada organ yang terkena cahaya matahari, kloroplas muda akan aktif membelah (Salisbury dan Ross 1991).

Kloroplas terutama berfungsi adalah sebagai tempat berlangsungnya fotosintesis. Pigmen-pigmen pada membran tilakoid akan menyerap cahaya matahari atau sumber cahaya lainnya dan mengubah energi cahaya tersebut menjadi energi kimia dalam bentuk adenosin trifosfat (ATP) (Lakitan 2001). 
Pada tumbuhan tingkat tinggi, klorofil a dan klorofil b merupakan pigmen utama fotosintetik, yang berperan menyerap cahaya violet, biru, merah dan memantulkan cahaya hijau (Salaki 2000). Molekul klorofil adalah suatu derivat porfirin yang mempunyai struktur tetrapirol siklis dengan satu cincin pirol yang sebagian tereduksi. Inti tetrapirol mengandung atom $\mathrm{Mg}$ non-ionik yang diikat oleh dua ikatan kovalen, dan memiliki rantai samping. Sintesis klorofil terjadi melalui fotoreduksi protoklorofilid menjadi klorofilid a dan diikuti dengan esterifikasi fitol untuk membentuk klorofil a yang dikatalisis enzim klorofilase. Perubahan protoklorofilid menjadi klorofilid a pada tumbuhan angiospermae mutlak membutuhkan cahaya. Selanjutnya klorofil jenis yang lain disintesis dari klorofil a (Pandey dan Sinha 1979).

Tanaman mangga (Mangifera indica L.) menunjukkan perbedaan warna dalam pertumbuhan daunnya. Daun pada pucuk biasanya berwarna kemerahan, keunguan, atau kekuningan, daun muda berwarna hijau kekuningan, dan daun tua berwarna hijau gelap. Perbedaan warna daun menunjukkan adanya perbedaan kandungan pigmen daun termasuk pigmen klorofil. Kajian analisis kandungan klorofil ini masih terbatas, penelitian ini dilakukan untuk memberikan informasi ilmiah tentang kandungan klorofil daun mangga (Mangifera indica L.) pada tingkat perkembangan daun yang berbeda. Informasi ini merupakan data awal atau pembanding untuk penelitian yang berhubungan dengan kandungan klorofil pada suatu tumbuhan.

\section{METODOLOGI PENELITIAN Alat dan bahan}

Peralatan yang digunakan adalah kantong plastik, kertas label, alat tulis, timbangan analitik, lumpang dan alu porselin, tabung reaksi, rak tabung reaksi, labu ukur, gelas ukur, saringan, termos es, gunting, aluminium foil, kamera digital dan spektrometer (Novaspec III). Bahan yang digunakan adalah daun mangga (Mangifera indica L.) dengan tingkat perkembangan daun yang berbeda, alkohol 95\%, akuades, es batu dan tissue.

\section{Prosedur Penelitian}

Langkah-langkah

sebagai berikut:

adalah

\section{Persiapan Sampel}

1. Sampel daun mangga diambil dari Kelurahan Kleak Kecamatan Malalayang.

2. Daun mangga dipetik dari pohon, sesuai tingkat perkembangan daun yaitu pucuk, daun yang muda dan daun yang sudah dewasa. Daun pucuk berwarna merah kecoklatan, daun muda 1 berwarna hijau kekuningan, daun muda 2 berwarna hijau muda dan daun tua berwarna hijau tua.

3. Untuk tiap tingkat perkembangan diambil 3 buah daun dengan 3 kali ulangan.

4. Daun dimasukkan dalam kantong plastik secara terpisah sesuai dengan kelompoknya untuk dianalisis kandungan klorofilnya di laboratorium.

\section{Analisis Klorofil}

1. Helaian daun (lamina) tiap sampel diambil sebanyak 1 gram, dihaluskan dan diekstraksi dengan alkohol 95\% sampai semua klorofil terlarut.

2. Ekstrak disaring dan supernatan ditampung dalam labu ukur 100 $\mathrm{mL}$, Ialu ditambahkan alkohol 95\% sampai $100 \mathrm{~mL}$.

3. Ekstrak dipindahkan ke dalam tabung reaksi, dan dimasukkan ke dalam termos yang berisi es.

4. Kandungan klorofil diukur dengan spektrometer pada $\lambda$ 649 dan $665 \mathrm{~nm}$. 
Kadar klorofil total dihitung dengan rumus Wintermans dan de Mots dalam Dahlia, (2001) :

Klorofil Total $(\mathrm{mg} / \mathrm{L})=20\left(\mathrm{OD}_{649}\right)+$ $6,1\left(\mathrm{OD}_{665}\right)$

Keterangan: OD (optical density) = nilai absorbansi klorofil

\section{Analisis Data}

Data dianalisis dengan menggunakan ANAVA pada taraf signifikansi $5 \%$ dan dilanjutkan dengan Uji Beda Nyata Terkecil (Hanafiah 2004).

\section{HASIL DAN PEMBAHASAN}

Kandungan klorofil daun mangga tertinggi terdapat pada daun mangga yang tua yaitu $47,44 \mathrm{mg} / \mathrm{L}$, dan kandungan klorofil terendah diperoleh pada daun mangga yang berwarna merah kecoklatan/pucuk yaitu 14,8 mg/L (Tabel 1).

Tabel 1. Kandungan klorofil daun mangga pada tingkat perkembangan daun yang berbeda

\begin{tabular}{|l|l|}
\hline $\begin{array}{l}\text { Tingkat } \\
\text { Perkembangan }\end{array}$ & $\begin{array}{l}\text { Rata- rata } \pm \\
\text { SD }\end{array}$ \\
\hline Daun merah & $14,80 \quad \pm$ \\
kecoklatan & $0,63 \mathrm{a}$ \\
Daun hijau & $20,90 \quad \pm$ \\
kekuningan & $4,76 \mathrm{~b} \quad$ \\
Daun hijau muda & $27,55 \quad \pm$ \\
& $3,76 \mathrm{~b} \quad$ \\
Daun hijau tua & $47,44 \quad \pm$ \\
& $2,03 \mathrm{c}$ \\
\hline
\end{tabular}

Keterangan: SD, standar deviasi; angka ynag diikuti oleh huruf berbeda adalah berbeda pada taraf signifikansi 5\%

\section{Pembahasan}

Klorofil adalah kelompok pigmen fotosintesis yang terdapat dalam tumbuhan, menyerap cahaya merah, biru dan ungu, serta merefleksikan cahaya hijau yang menyebabkan tumbuhan memperoleh ciri warnanya (Anonim 2006). Semua jenis plastida termasuk klorofil berasal dari protoplastida, yakni suatu organel tidak berwarna yang dijumpai pada sel tumbuhan yang tumbuh di tempat gelap dan terang (Lakitan 2001).

$$
\text { Kandungan klorofil daun }
$$
bertambahnya umur daun (Tabel 1). Kandungan klorofil rata-rata pada pucuk dengan warna daun merah kecoklatan yaitu $14,8 \mathrm{mg} / \mathrm{L}$, daun hijau kekuningan yaitu $20,9 \mathrm{mg} / \mathrm{L}$, daun hijau muda yaitu $27,55 \mathrm{mg} / \mathrm{L}$, dan daun hijau tua yaitu $47,44 \mathrm{mg} / \mathrm{L}$.

Kandungan klorofil pada daun merah kecoklatan ada tetapi berjumlah sedikit. Klorofil pada daun mangga yang masih muda masih berupa protoklorofil dan daun menjadi berwarna hijau setelah transformasi protoklorofil.

Warna daun merah kecoklatan pada pucuk menunjukkan karotenoid merupakan pigmen dominan pada tingkat perkembangan tersebut. Karotenoid banyak terdapat pada organisme fotosintetik, seperti alga, tumbuhan tinggi dan bakteri fotosintetik. Karotenoid biasanya memberikan warna merah, coklat, oranye dan kuning (Danks et al. 1983).

Perubahan warna daun dari merah kecoklatan menjadi hijau kekuningan menunjukkan adanya perubahan kandungan pigmen pada daun. Hasil analisis klorofil menunjukkan adanya peningkatan kandungan klorofil sebanyak 6,1 $\mathrm{mg} / \mathrm{L}$ dari daun warna merah kecoklatan menjadi hijau kekuningan.

Klorofil disintesis dengan cara fotoreduksi protoklorofilid menjadi klorofilid a, yang diikuti oleh esterifikasi fitol membentuk klorofil a. Klorofil a juga terdapat pada daun dengan warna merah kecoklatan tetapi dengan jumlah sedikit. Selanjutnya xantofil dibentuk melalui penggabungan molekul oksigen dengan karoten yang menyebabkan daun berubah warna menjadi hijau kekuningan. Sintesis klorofil a dari klorofilid a tidak membutuhkan 
cahaya., Perubahan protoklorofilid menjadi klorofilid a pada Angiospermae mutlak membutuhkan cahaya, tetapi pada Gymnospermae (beberapa paku-pakuan dan alga, klorofil dapat dibentuk dalam keadaan gelap (Pandey dan Sinha 1979).

Kandungan klorofil pada daun hijau kekuningan $32 \%$ lebih tinggi daripada daun mangga warna hijau muda meningkat dari 20,90 menjadi $27,55 \mathrm{mg} / \mathrm{L}$. Pada tingkat perkembangan daun ini terjadi sintesis klorofil b dari klorofil a dengan jumlah yang besar, yang diikuti dengan berkembangnya daun tersebut. Sintesis klorofil b terus berlanjut bersamaan dengan perkembangan daun yang ditandai dengan berubahnya warna daun hijau muda menjadi hijau tua. Kandungan klorofil pada daun warna hijau tua $72 \%$ lebih besar daripada daun warna hijau muda. Klorofil $b$ dibentuk dari klorofilid a atau klorofil a (Wolf dan Price dalam Pandey dan Sinha 1979).

Klorofil a dan b merupakan pigmen utama yang terdapat dalam membran tilakoid. Selain kedua pigmen ini terdapat pula pigmenpigmen kuning sampai jingga yang disebut karotenoid. Ada dua jenis karotenoid yaitu karoten (murni hidrokarbon) dan xantofil (mengandung oksigen). Semua klorofil dan karotenoid terikat pada molekul protein oleh ikatan nonkovalen (Lakitan 2001).

Faktor-faktor yang berpengaruh terhadap pembentukan klorofil antara lain gen, cahaya, dan unsur N, Mg, Fe sebagai pembentuk dan katalis dalam sintesis klorofil. Semua tanaman hijau mengandung klorofil a dan klorofil b. Klorofil a menyusun $75 \%$ dari total klorofil. Kandungan klorofil pada tanaman adalah sekitar $1 \%$ berat kering (Subandi 2008).

Kemampuan daun untuk berfotosintesis juga meningkat sampai daun berkembang penuh, dan kemudian mulai menurun secara perlahan. Daun tua yang hampir mati, menjadi kuning dan tidak mampu berfotosintesis karena rusaknya klorofil dan hilangnya fungsi kloroplas (Sestak 1981).

\section{KESIMPULAN}

Berdasarkan hasil penelitian yang dilakukan, dapat disimpulkan bahwa

1. Rata-rata kandungan klorofil daun mangga warna merah kecoklatan (pucuk) adalah 14,8 $\mathrm{mg} / \mathrm{L}$, warna hijau kekuningan adalah 20,9 mg/L, warna hijau muda adalah $27,55 \mathrm{mg} / \mathrm{L}$ dan warna hijau tua adalah 47,44 $\mathrm{mg} / \mathrm{L}$.

2. Kandungan klorofil daun mangga berbeda pada tingkat perkembangan yang berbeda.

\section{DAFTAR PUSTAKA}

$$
\begin{array}{ll}
\text { Anonim } & \begin{array}{l}
(2006) \text { Klorofil http: } \\
\text { Klorofil//id. }
\end{array} \\
& \text { Wikipedia.Org/wiki/kloro } \\
& \frac{\text { fil Diakses pada } 26}{\text { Februari 2010. }}
\end{array}
$$

Danks SM, Evans, Whittaker PA (1983) Photosyinthetic system. John Willey \& Sons, New York

Dahlia MS, Lukiaty B, Kusumaputri SS (2001) Petunjuk praktikum fisiologi tumbuhan. Fakultas MIPA UM, Malang

Hanafiah KA (2004) Rancangan percobaan dan teori aplikasi. Fakultas Pertanian Universitas Sriwijaya, Palembang

Lakitan B (2001) Dasar-dasar fisiologi tumbuhan. Raja Grafindo Persada, Jakarta

Pandey SN, Sinha BX (1979) Plant physiology. Vikas Publishing House FVT Ltd, NewDelhi

Salaki M (2000) Biologi sel. Proyek Pengembangan 


\author{
Perguruan Tinggi \\ Indonesia Timur \\ Kerjasama Universitas \\ Sam Ratulangi Canadian \\ Internasional Development \\ Agency Simon Fraser \\ University \\ Salisbury FB, Ross WC (1991) \\ Fisiologi tumbuhan. Jilid 2. \\ ITB, Bandung \\ Sasmitamihardja D, Siregar A (1997) \\ Fisiologi tumbuhan. \\ Jurusan Biologi FMIPA - \\ ITB. Proyek Pendidikan \\ Tenaga Akademik \\ Direktorat Jenderal \\ Pendidikan dan \\ Kebudayaan, Bandung. \\ Subandi A (2008) Metabolisme. \\ http://metabolisme.blogs \\ pot.com/2007/09. Diakses \\ pada 29 April 2010 \\ Sestak Z (1981) Leaf ontogeny and \\ photosynthesis, \\ physiological processes \\ limiting plant productivity. \\ Butterworths, London
}

